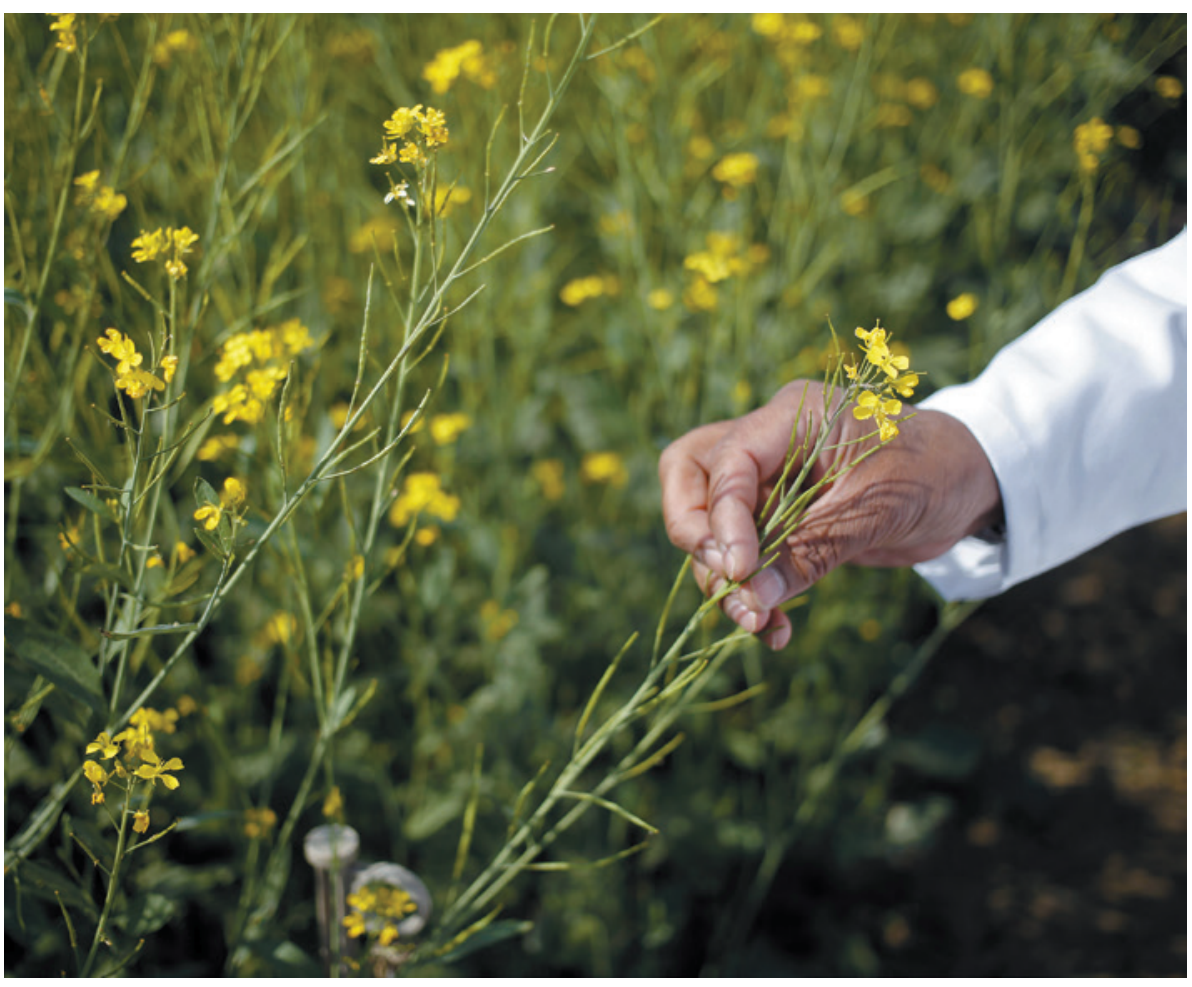

Genetically modified mustard is being grown in fields in New Delhi.

\title{
BIOTECHNOLOGY
}

\section{India eases stance on GM crop trials}

\section{States begin to permit field tests of transgenic plants.}

\section{BY SANJAY KUMAR}

$\mathrm{F}$ ive years ago, India was a hostile place for researchers testing genetically modified (GM) crops. Its government barred the commercial planting of a transgenic aubergine (a vegetable locally known as brinjal) after protests from anti-GM activists. Then it gave state governments the power to veto transgeniccrop field trials. The result: an effective moratorium on such trials. "We felt as if we had come up against a brick wall, and might as well chuck it in and do something else," says molecular biologist Bharat Char, who works for Maharashtra Hybrid Seeds Company (Mahyco), a firm in Jalna that pioneered the GM brinjal (and in which agricultural giant Monsanto holds a minority stake).

But under the government of Prime Minister Narendra Modi, voted into power a year ago, India has quietly changed course on GM field testing. In the past year, eight Indian states largely aligned with Modi's Bharatiya Janata Party have approved field trials of GM crops, between them allowing tests that include transgenic rice, cotton, maize (corn), mustard, brinjal and chickpea, according to documents seen by Nature (see 'GM crop trials'). "There is no better feeling than to know that your technology is performing in the field," says Char, who himself planted salt-tolerant GM rice in Maharashtra state in January.

\section{DEVELOPMENT TENSIONS}

The relaxed attitude to GM crop trials is not only reviving the enthusiasm of Indian biotech researchers - it will also be keenly watched around the world, says Dominic Glover, an agricultural socio-economist at the University of Sussex in Brighton, UK. "India's attitude towards transgenic crops has a symbolic importance beyond its borders," he says, because it epitomizes tensions that surround the use of

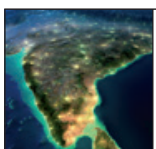

SCIENCE IN INDIA

A Nature special issue nature.com/indiascience
GM technology in developing nations.

On the one hand, India must improve its agricultural productivity to feed its rapidly growing population. The country should thus embrace GM efforts to develop higheryield crops that are resistant to pests or grow well in droughts or harsh environments such as salty soil, says biochemist Govindarajan Padmanaban, former director of the Indian Institute of Science in Bangalore.

On the other hand, India has more than 100 million farmers, who are concerned that if GM crops become prevalent, their livelihoods and the nation's food supply will increasingly rely on expensive, rapidly changing and proprietary seed technologies owned by large corporations, says Glenn Stone, an environmental anthropologist at Washington University in St. Louis, Missouri.

These tensions erupted in 2010, when farmers and anti-GM groups organized huge public protests that led to the brinjal ban (see Nature http://doi.org/bkt7dh; 2010). And they regularly flare up in criticisms of India's 2002 adoption of GM cotton, which contains genes to ward off certain insects. This is the country's only permitted commercial GM crop, but it is grown in such quantities that India is the world's fourth-biggest GM-crop producer, behind the United States, Brazil and Argentina.

\section{SLOW PROGRESS}

The new lenience on GM field trials has not reached all of India: more than 20 states and territories are still exercising their vetoes. In meetings between March and July last year, the Genetic Engineering Appraisal Committee (GEAC), part of India's environment ministry, granted permission to 80 field-trial applications, but state-government blocks meant that many of the trials were never begun.

These local bottlenecks have mainly hurt biotech researchers in India's universities and public-sector institutions, says Padmanaban: they retard the progress of domestic technology, whereas multinational firms such as Monsanto can test GM crops elsewhere. Akshay Pradhan, a geneticist working on transgenic mustard plants with the University of Delhi's Centre for Genetic Manipulation of Crop Plants, says that his team had its technology ready as far back as 2002 but is only now resuming field trials after a twoyear hiatus. "This delay has surely thwarted its commercialization," he says. Agricultural scientists want faster progress: in February, some petitioned Modi to lift barriers including the requirement to seek state-government approval for field trials after getting the thumbs-up from the environment ministry.

But activists and non-governmental organizations (NGOs) argue that India should be wary of welcoming transgenic crops. They frequently raise concerns that such crops may be unsafe for the environment or human health, and that Indian regulators have conflicts of 
un interest and have not put in place sufficient mechanisms to carefully monitor field trials. Similar criticisms were raised in 2012 by a 崫 technical committee convened by India's Supreme Court. The court is still considering a moratorium on planting GM crops (including in field trials), which anti-GM activists requested in a petition a decade ago.

One issue that critics and scientists agree on is the need for legislation to improve biotech-

nology regulations. A regulatory bill that failed to get through parliament in 2013 is now being revised, but could take two years or more to be passed, says Sunkeswari Raghavendra Rao, an adviser to the government's Department of Biotechnology.

\section{COMMERCIAL CAUTION}

India's government seems to be treading much more cautiously on commercial cultivation of transgenic crops than on field trials although farmers in neighbouring Bangladesh began cultivating GM brinjal last year. (Some policy-makers who do not want to be named are concerned that the brinjal, or its seeds, will make its way into India anyway, over the porous Indo-Bangladesh border.)

But the government seems reluctant to engage in transparent debates about the pros and cons of pushing forward the use of GM biotechnology in India, as well as about

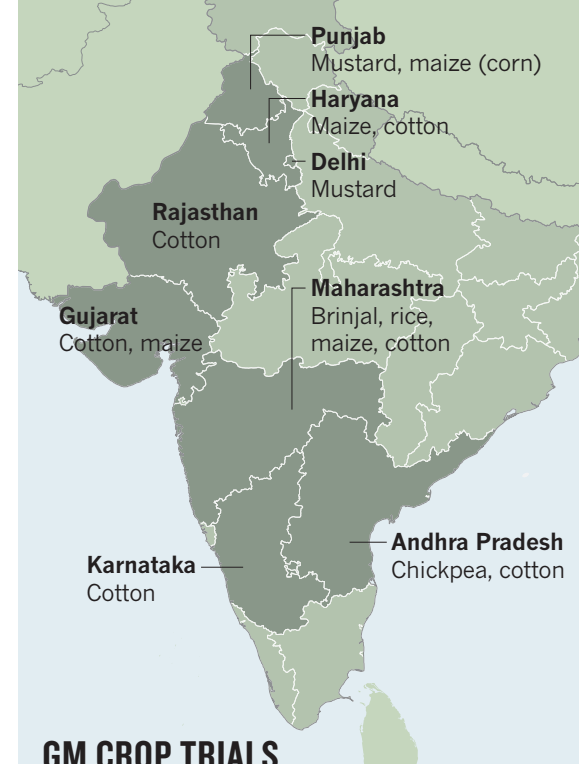

Transgenic field crop trials have taken place in eight Indian states and territories over the past year.

the details of field trials being allowed in the country. Details of GEAC meetings that used to be publicly posted on its website now no longer appear online, and GEAC officials would not talk to Nature for this article. "I find this secrecy shocking and absurd," says Pushpa
Bhargava, a retired molecular biologist whom the Supreme Court has nominated to attend GEAC meetings. And the government has come under fire for freezing the bank accounts of the Indian branch of environmental NGO Greenpeace. It has cited financial irregularities, which Greenpeace denies, but a widely leaked intelligence report prepared for Modi last year stated that the group's anti-GM campaigning was thwarting India's development.

\section{CORRECTIONS}

The graphic in the News story 'Pluto mission hunts for hazards' (Nature 521, 14-15 2015) put Nix on the wrong orbital path. The correct image can be seen at go.nature.com/ sbpxsu. The News story 'Pint-sized DNA sequencer impresses first users' (Nature 521, 15-16; 2015) mistakenly stated that the MinION device has problems reading long, repetitive regions of DNA sequence. It should have said that those difficulties occur in sections of genome that are rich in long stretches of a single DNA base. And the reference list in the News story 'Mysterious galactic signal points LHC to dark matter (Nature 521, 17-18; 2015) omitted two entries. The complete list can be seen at go.nature.com/mzopta. 